\title{
Civil Service Management in Devolved Government: Reconciling Local Accountability and Career Incentives in Pakistan
}

\section{Musharraf Rasool Cyan*}

\begin{abstract}
This paper looks at the case of Pakistan's decentralization reform of 200109 and its impact on civil service management. A key point made in this paper is that the relationship between organizational change and civil service is, by no means, unidirectional. The issues are viewed in the context of decentralization, its opportunities, and outcomes for efficiency and equity. We then evaluate whether administrative decentralization has enhanced or diminished the potential for political and fiscal decentralization for service delivery in Pakistan.
\end{abstract}

Keywords: Decentralization, government, civil servant, Pakistan.

JEL classification: $\mathrm{H} 10$.

\section{Introduction}

Decentralization is a reform that creates multiple tiers of governmental authority. As local (or provincial) governments are created or empowered, they gain the attributes of government, including the authority to hire and manage a civil service. This component of government authority is critical to the performance of governments at each level. The civil service is a key instrument in the implementation of public sector policies and programs. Civil servants manage departments that implement policies and programs, monitor inputs and outputs, project government authority as a means of social regulation, and administer tax and expenditure instruments in different subnational jurisdictions. The quality of the civil service often considerably influences service delivery, as well as regulatory and developmental outcomes. Decentralization reform brings about a number of changes, chief among them the dispersal of government authority over a large number of actors and levels. Transition from a centrally managed system of government to a decentralized order

\footnotetext{
* Research Associate, International Center for Public Policy, Andrew Young School of Public Policy Studies, Georgia State University.
} 
of numerous governments on one hand affects centralized civil service in a major way by creating decentralized authorities for it. On the other hand, decentralization is implemented with the objective of maintaining baseline service levels, which may or may not be suited to transition to a decentralized order of government.

This article discusses primarily the case of a central civil service working in devolved governments, and its half-way mutation into localized civil services. It contributes to the debate on decentralization, using the case of Pakistan's decentralization reform of 2001-09 and its impact on civil service management. The specific study is a case of Weberian bureaucracy adapting to an increase in demand for performance and accountability, while central controls and standards loosen to accommodate its placement in devolved units of government. A key point made in this discussion is that the relationship between organizational change and civil service is, by no means, unidirectional. The issues are viewed in the context of decentralization, its opportunities, and outcomes for efficiency and equity. The analysis applies to management cadres specifically but is also relevant to other public servants. We then evaluate whether administrative decentralization has enhanced or diminished the potential for political and fiscal decentralization for service delivery. Let us say that this is nontrivial-ours is a specific focus and we do not attempt to cover all issues related to decentralization in Pakistan.

In Pakistan, the local government reforms of 2001 created a large number of decentralized governments that inherited their mantle from deconcentrated provincial government units. The major part of the transition took place over a year, but some of the changes took longer. When it was thought that decentralized local governments would be stabilized, in 2009 the decentralization program was rolled back, starting with the provinces and centralizing functions once again. That civil service management moved from centralized to some form of decentralized and then back to centralized organization at the end of this period reveals a number of issues pivotal to decentralization reform.

Section 2 recounts key features of devolution in Pakistan. Section 3 discusses how administrative decentralization is related to devolution in general. Section 4 describes how decentralization affected centrally managed civil services at the provincial and local level in Pakistan and, in turn, how decentralization outcomes were reshaped by the central nature of the civil service. Following this discussion, we summarize some important lessons that emerge from Pakistan's case. Section 5 concludes the article. 


\section{Decentralization in Pakistan: Another Round of Reform}

In 2001, the fourth military government in Pakistan initiated a major decentralization reform-the third round of local government reforms in the country. Major provincial mandates were decentralized to 6,125 newly created local governments. The creation of these local governments was made possible through the near simultaneous adoption of four statutes in the provinces of Punjab, Sindh, the then North West Frontier Province, and Balochistan. Major structural changes took place. The deconcentrated units of provincial service delivery departments were devolved to the new local governments. Each local government had an indirectly elected political executive and a directly elected councilbudgetary authorities were vested in the council. The four provinces decentralized education, health, roads, drinking water supply, and a number of regulatory functions to the local governments by enacting centrally crafted legislation.

The local government was established as a three-tier structure with an almost nonhierarchical relationship among the tiers. The first level of local government was the district. Across the country, 109 district government were created by bringing together the deconcentrated units of 11 provincial departments. Of these, four districts were classified as city districts with additional urban planning and municipal functions. Below district level, the second tier comprised 396 tehsil municipal administrations (TMAs). The TMAs were created out of the nodes of earlier local governments established in 1979 by including their surrounding rural hinterland. The lowest tier of local government comprised the union administrations, each with a population of around 25,000. Each of the three tiers of local government had an elected council and an elected executive called a nazim. The union nazim was directly elected but the TMA and district nazims were elected by a college of all the councilors in the jurisdiction. Table 1 shows the number of local governments created from deconcentrated provincial government offices and earlier local governments. 
Table 1: Local governments in Pakistan

\begin{tabular}{lccc}
\hline Province/region & Districts/city districts & $\begin{array}{c}\text { Tehsils/ } \\
\text { towns }\end{array}$ & $\begin{array}{c}\text { Union } \\
\text { councils }\end{array}$ \\
\hline Punjab & 35 & 144 & 3,464 \\
Sindh & 23 & 121 & 1,108 \\
North West Frontier Province & 24 & 54 & 986 \\
Balochistan & 28 & 77 & 567 \\
Capital Territory & 1 & & \\
Total & 111 & 396 & 6,125 \\
\hline
\end{tabular}

The new local governments inherited the old civil service structures and human resources. Prior to the creation of new local governments in 2001, the deconcentrated districts were managed by provincial or federal cadre officials. Officers with the same or changed responsibilities continued working in the decentralized departmental units. Changes in responsibilities affected mostly general cadre officials. In all cases, reporting responsibilities at the senior-most level in the local governments changed materially, as described below. The level of changes was given in the local government statutes. This provided legal legitimacy as well as incontrovertibility. Compared with certain other countries, administrative decentralization in Pakistan reached an intermediate decentralization with some management functions decentralized to local governments and others retained at the provincial level (Evans \& Manning, 2003). The statutes defined the basic structures of local government. Over time, these changes were implemented through regulations and rules. In some cases, practice defined the changes and assigned meaning to them. It is at this level of detail that we focus our discussion to highlight the effects of decentralization reform on the civil service and the ways in which it has, in turn, shaped decentralization outcomes.

Not all local governments were alike. The city district government of Karachi had a population of 15 million-the country's largest local government while the rural district government of Killa Saifullah in Balochistan had a population of 0.5 million. The implementation of decentralization reforms recognized this diversity as an issue that required uniform treatment rather than providing opportunities to evolve a variety of solutions to achieve a qualified civil service for all local governments. Officially, civil servants' salaries remained in the provinces' purview, but were practically determined by the federal government. This meant that civil servants serving in Karachi or Killa Saifullah would expect similar 
remuneration on comparable pay scales. This was one of the foremost features of administrative decentralization seeking to provide all types of local governments with equivalent skill levels.

Civil servants were transferable between local governments according to their cadre domains, but with some exceptions to this general dispensation. The positions of district heads of department in city districts were on higher pay scales than in ordinary districts. In handing over controls over civil services, provinces in this manner laid down strict parameters, leaving little room for local governments to adopt locally suitable options. This approach ensured that the services of qualified civil servants were available to even small and poor districts. For rich districts, however, it was an unnecessary constraint that reduced their scope for local initiatives-a key objective of decentralization. For example, the city district government of Karachi could not hire a professionally qualified individual to manage its finance and planning office, although it offered a competitive salary. It was obliged to post a federal or provincial civil service to the position. The quest for uniformity thus guided policy but in fact resulted in widely varying arrangements across districts.

Administrative decentralization moved a large number of civil servants under local government control. On the basis of budgetary data, in 2009 there were a total of $1,018,579$ positions in Punjab. Of these, 657,824 moved to 36 district governments, 1 i.e., devolution resulted in the assignment of 64.58 percent of government employees to district governments. This change on the surface was material, where many provincial departments lost their field offices to local governments. In practice, the provinces retained a number of controls over their civil servants while working in the districts. These controls were most heavily exercised over senior civil servants, including the chief district government civil servant or district coordination officer (DCO), sector chiefs or executive district officers (EDO), and other management officers.

Salary budgets were progressively decentralized but still controlled by the provinces through strictly defined salary bands and increments. In many cases, the provincial government also set the size of the local government establishment. From 2004 to 2008, 46,546 teachers were recruited in various districts of Punjab. All the positions were first approved by the provincial government before being incorporated into the local government establishment schedules. From 2001 to 2008, two rounds

${ }^{1}$ The total number does not include the TMA positions that were not financed from the provincial budget. 
of elections took place. In the first round, 87,000 councilors were elected to local governments; one third of these were women. By the time of the second election in 2005, the number of local council seats was reduced; as a result, 38,000 councilors reached the local councils.

Together, the elected councils and local executive exercised political control over the decentralized civil servants but to varying degrees. As discussed in Section 4, the establishment of political leadership and control over district-level civil services created a new working environment for the centrally managed cadres of the civil service, changing performance incentives and accountability arrangements. The demand for improved services became a common expectation in districts that had previously been concerned with basic public order concerns. The large number of elected councilors with local constituencies exposed the civil service to new pressures for performance-a major break with the past. However, while central controls were considerably weakened, they were not completely obliterated.

Before returning to the specific details of how decentralization created civil service structures at local levels, and how the civil service with lingering centralized management played out in Pakistan, it is useful to lay down the general perspective in which this analysis is carried out. The next section deals with this discussion.

\section{Major Changes for the Civil Service under Decentralization}

Decentralization creates multiple levels of government as well as a number of governments, horizontally. At each level and in each unit, political authority directly accountable to the local citizenry comes into being. Prior to decentralization, the locally based civil service receives policy directions and implementation commands through its own hierarchy, and political control is exercised at the central level. This is one of the most far-reaching changes for the civil service after decentralization. The extent of authority vested in each government determines the roles and responsibilities of the civil service. The political and fiscal dimensions of decentralization make administrative decentralization necessary. The type of decentralization that is actually carried out may vary according to the specific context and objectives of the reform.

Among other things, decentralization disperses authority and creates new responsibilities for the civil service and competition between local autonomy and central standards (World Bank, 2011). Devolution 
creates multiple levels of legitimacy to replace the known central authorities. $^{2}$ For the civil service, this creates internal pressure to accommodate new definitions. The centrally managed civil service is only accustomed to intra-departmental and interdepartmental dealings. For most of these cases, procedures, rules, and traditions provide a sufficiently comprehensive template for decisions and initiatives. Devolution creates an undefined territory of intergovernmental relations that may not fit very well with the customary norms and traditions of civil service (Parry, 2008). Thus, as happened in Pakistan, mid-career civil servants assigned to the newly created local governments found themselves resolving intergovernmental affairs for which they were not prepared.

The objective of this transition is to get the civil service to report to its new authorities without compromising on centrally sustained standards. If the central standards are weak, then the transition may lead to problems for local governments, but where they constrain local initiatives, in time such weakening may also create opportunities for development. In all Pakistan's four provinces, less regard was paid to maintaining official standards and there was greater focus on assigning officials to districts and TMAs. Although four transition teams with administrative powers were created in each province, the new councils were inexperienced in asserting political control over the newly decentralized civil service. They did not receive much guidance on how to put into operation any of the number of mechanisms narrated in the law to assert policy direction, control, and performance accountability on the devolved district entities. ${ }^{3}$ As in other cases of devolution, the civil service gravitated toward retaining central (or provincial) codes for management rather than dealing with the enormous task of devising local codes. ${ }^{4}$ The reluctance to open up the possibility of writing new codes was also a result of the civil service's anxiety at facing new challenges to their processes from inexperienced local politicians.

Decentralization or devolution in various countries has been accompanied by changes in centrally managed civil service systems. Some degree of central control and linkages of civil service serve the transition well. Among the advantages is working through complex and evolving intergovernmental relations. Central civil servants assigned to devolved

\footnotetext{
${ }^{2}$ See, for example, Goodwin, Jones, and Jones (2005) for a discussion of the complex division of the state following devolution in the United Kingdom.

${ }^{3}$ Most of the capacity-building initiatives focused on developing typical civil service capacities. Some program linked with councilors but as they were mostly implemented by NGOs they did not venture into core government capacities.

${ }^{4}$ The case of Welsh devolution also kept central civil service codes attempting to keep previous position with ministers (Cole, Jones, \& Storer, 2003).
} 
governments can work well with their centrally placed colleagues to resolve issues and find solutions (Parry, 2001). At the same time, civil servants assigned to local governments may face obsolescence of customary administrative norms. Moreover, middle-level civil servants may immediately be assigned to chief positions in local governments. This increases the pressure on civil servants trained to working within the welldefined precincts of centrally controlled departments, and is often inadequately documented (see Pyper, 1999).

\section{Decentralization and the Civil Service in Pakistan}

This article does not treat the civil service as a passive mechanism with no discretion to react to devolution. It is a key player in decentralization and acts by shaping its outcomes. Like any other player, the civil service does not control the process completely, but through its longevity and persistence, it perhaps plays a more important role than other actors. In the case of Pakistan, the civil service outlasted other actors, namely the military regime (1999-2002), the quasi-military government (2002-08), and the constitutional provisions protecting local governments (2002-09). The creation of local governments in Pakistan was a major change for the political and administrative traditions of Pakistan. ${ }^{5}$ In one swathe of reform, the civil service was moved into multiple spheres of authority and responsiveness. This section discusses the transition.

In general, decentralization created a new incentives framework for the civil service. Local governments had two key types of features to enhance citizen control over government. The first type of controls was the ex-ante policymaking role that was passed on to the elected local executive. The second type was ex-post and could be exercised through council committees. The nazims exercised policy control primarily by identifying development projects. In many other areas, their role remained constrained due to informal controls exercised by the provincial departments through budgetary mechanisms or civil service management. The committee reviews remained rare and council committees did not become functional (Asian Development Bank, UK Department for International Development, World Bank, 2004).

The following key changes took shape, changing civil service structures and incentives and, in turn, being reshaped by the civil service.

\footnotetext{
${ }^{5}$ The Pakistani administration is much closer to the Napoleonic administration tradition described in Peters (2008). A relevant discussion of public sector reform discussing the cases of France, Greece, Italy, Portugal, and Spain is given in Ongaro (2008).
} 


\subsection{Atomized Authority and Control}

The new local governments of 2001 led to the structural recreation of the district- and tehsil-level local governments. For the provincial civil service (and assigned federal civil service), this was a major change. As shown in Table 1, a number of new authorities were created for the civil servants in each province. District and subdistrict offices attuned to centralized control from their departments were placed under the authority of elected offices in each of 505 local governments. The authority to set policies, prioritize programs, make budgetary allocations, and demand performance was allocated to 6,125 local governments, replacing a handful of departments. For the body of civil servants, this created a completely new framework of performance. As a whole, the provincial civil service in each province could no longer respond to unified central control exercised by their provincial government. Partial decentralization of performance evaluation and the authority to transfer civil servants reoriented them toward new nodes of authority. ${ }^{6}$

Had the law had complete sway, this would have meant that civil servants posted in the districts would have been completely submerged by the local legal authority. The law's intent, however, was considerably diminished by the civil service's instruments. In Punjab, the provincial civil service was reorganized paying only scant attention to local governments and the need to establish local accountability. For the reorganized provincial civil service, key positions in local governments were enumerated as career positions, upward mobility toward provincial-level positions was guaranteed, and no mention was made of local performance evaluation. ${ }^{7}$ As a result of these two parallel but opposite actions, a compromise between local autonomy and central control was achieved. Atomized authority was accepted but strong incentives were created for looking up to the central authorities for career paths.

\subsection{Multiple Controls and Directions}

The traditional civil service was enmeshed in rules emanating from a single authority and honed over more than a century. It acted as a vehicle of central policies and was responsible for implementing central programs among local populations. Informal rules and institutions, such as those for dealing with political leaders and reducing the intensity of local conflicts,

\footnotetext{
6 Through statutory provisions, the performance evaluation reports of senior civil servants assigned to local governments were given to local elected heads of government.

${ }^{7}$ For details, see Punjab, Services and General Administration Department (2004).
} 
had emerged over time. The latter overlay the formal rules and, together, created the template for civil servants' behavior. The functional arrangement in the centrally managed districts was not defined by formal rules alone.

Local government reform increased the complexity of this arrangement by introducing multiple controls and policy directions for the civil service. Nazims were invested with formal authority as heads of local government for budget making and management. For the sectoral departments, effective control over postings and transfers and budgetary approvals were vested at the district level. At the same time, departments and provincial government retained formal and informal levers to influence decisions and management in local governments. Between 2007 and 2009, the district heads of sectoral departments were torn between provincial orders and local priorities. ${ }^{8}$ With time, the provincial need to retain a major say in the districts was manifested in the time spent by district heads in the provincial capital for meetings and reports. Despite the availability of technological options for monitoring and reports, personal presence was often considered mandatory. This showed that provincial authorities continued to exercise strong controls over decentralized departments.

Interviews with DCOs showed that it was common for nazims' priorities and directions to be at variance with provincial directions and expectations. Since the former's career incentives were linked with the province, in most cases they would find a way to ignore the nazim's priorities and directions. In certain cases, where the nazim was a political ally of the provincial government, he or she could have the provincial directions revoked. DCOs were alert to this possibility and used this channel of communication before making a final decision to comply. DCOs performed functions that were far complex than the traditional development managers. ${ }^{9}$ Many times, the district management thrust civil servants into roles that were political rather than traditionally administrative. ${ }^{10}$

A clear case of multiple controls emerged in education and health. Both sectors were decentralized to the districts. With a number of vertical

\footnotetext{
${ }^{8}$ Based on the author's interviews of education and health EDOs in Multan, Faisalabad, and Jhang. DCOs in Lodhran, Multan, Faisalabad, Jhang, and Rawalpindi also reported a long series of meetings being held at the provincial headquarters every month.

${ }^{9}$ Gulrajani (2010) presents a discussion on changing roles.

${ }^{10}$ This was in line with the political role of civil servants observed in other contexts (for example, see McGregor, 1974). In this case, middle-level civil servants were exposed to this role. The change remained short of politicization seen in another closed career system such as that in Germany (Derlien, 2003).
} 
programs, reporting authorities were created for specific types of sector activities. Many of these programs provided substantial finances to the district sectors, creating potent influences for the local government. Largescale donor programs added to this multi-directionality for the locally placed civil service by defining clear performance targets and reporting obligations for the province-level project offices.

\subsection{Enhanced Space for Senior Civil Servants in the Interstices of Intergovernmental Relations}

The creation of new local governments ushers in the opportunity for initiatives and modernization, which might otherwise take a long time to affect a tradition-bound civil service (Parry, 2005). Decentralization in the European Union was accompanied by the loosening of human resource management rules and regulations, increasing managers' discretion to make decisions (Meyer \& Hammerschmid, 2010). In Pakistan, the chief civil servant in the district government, the DCO, became an important office in the decentralized district. The DCO was given a central role in administrative decision making for all departments and budget making for the district government. This level of authority had not been seen in the district office since the colonial administration of the early to late twentieth century, where the district office worked as the fulcrum around which development administration worked. ${ }^{11}$

Intergovernmental relations between the province and local government negotiated many turns and twists between 2001 and 2009. The local government ordinances laid down statutory principles and created space for the evolution and amendment of rules and regulations to populate the mechanics of devolved sectors. The districts were given budgetary authority. Formally, this meant that the council could allocate funds received under the Provincial Finance Commission (PFC) grants and local revenues to district priorities. In practice, however, expenditure autonomy was limited in a number of important ways.

Almost four fifths of the district budget was allocated to salaries (Asian Development Bank, UK Department for International Development, World Bank, 2004). In theory, the district could transfer government servants from the districts and create vacancies to accumulate savings-this could be carried out by the DCO. In practice, DCOs would follow provincial directions. None of the 109 districts opted for layoffs to create fiscal space for

${ }^{11}$ The traditional development administration (Brinkerhoff, 2008) and its role was embedded in the district office. 
local priorities. Schoolteachers, the largest component of public employment in the district, were not reassigned among schools, and wide-ranging student-teacher ratios continued as before. Recruitments in education were decentralized to the district. DCOs chaired the committees, which followed a selection process and applied merit criteria laid down by the province. The most important function in the district was to obtain additional funds from the province. Despite the PFC awards, this continued to be a negotiated process in the presence of numerous federal and provincial vertical programs. Again, DCOs played a key role in these negotiations.

As they started to function on their own, local governments worked under provincial tutelage for funds, officers, rules and regulations, and even policy directions. The new arrangement created an unchartered territory of relations between provinces and local governments. DCOs were placed in the most important position in these relations, which were conducted mostly through discussions, meetings, and consultations. Civil servants tended to be risk-averse, however, and did not imbibe the spirit of local government reform, remaining bound to provincial policy directions. The overbearing departments did not help either (Williamson, Ahmad, \& Smith, 2005). Service providers such as teachers did not receive much support from district-level managers (Pakistan, Ministry of Education, and UNESCO, 2003).

The new space for discretionary work was a positive feature of decentralization, although no systematic data is available to document how this space was used. In some cases where data is available, it shows that initiative and timely action contributed to improved local government outcomes. In Punjab during 2002 and 2008, a total of 48,546 teachers were recruited at district level and placed in schools with vacancies. The entire recruitment and placement process was managed at district level without any major complaints regarding transparency or merit. Moreover, due to the greater discretion with contract appointments available to district-level managers, there was a marked improvement in the availability of doctors and health workers in rural health facilities (Cyan, 2009).

\subsection{Multiple Accountability Channels}

One of the most important changes that devolution brought about for the centrally managed civil service was the creation of multiple accountability channels. The elected councils and political executive in local governments were empowered to make local decisions. The primary

reporting lines for civil servants were redrawn toward the local political 
executive. Nothing less than specific statutory provisions assigned performance evaluation to the nazim. The councils were mandated to assign a number of committees to oversee the performance of decentralized departments. The most important of these committees was the accounts committee, which had the authority to receive and review audit reports.

The law had originally envisaged a decentralized civil service with local reporting and accountability. DCOs, as the principal accounting officers, would stand before the local committees to respond to audit objections. This was the most important legal provision intended to absorb the central civil service into the local accountability framework, but the situation was diluted by certain management provisions. First, senior provincial civil servants were assigned additional reporting responsibility. For all civil servants in charge of a sector, the departmental secretaries reviewed performance reports from the district and provided their own evaluation. According to the established rules of interpretation, the second evaluation holds sway if the two evaluations do not agree. For the DCO, the authority for the second evaluation was assigned to the provincial chief secretary. In this way, central controls were maintained over the devolved offices.

Second, the law clearly assigned the accounting function to local governments and empowered the local councils' accounts committee to audit reports. This was one of the key provisions establishing a local accountability arrangement for the devolved offices. The provision was, however, not put into practice in spirit. The federal auditor general initially opposed the idea of auditing local governments and then proceeded to establish 27 regional offices across the country to create subordinate field formations to audit local accounts. At the same time, there were attempts to centralize local accounts to the federal level. The audit reports were provided to the provincial governor who was authorized to forward them to the local councils. The weak capacity of the auditors and councils continued to undermine this provision. The provincial government found it more convenient to use the preliminary auditor's observations to lay accusations of unprecedented corruption against local governments in 2009. The accusations were not followed through, and once the expediency of controlling local governments through civil servants was achieved, the issue was forgotten. On the whole, these provisions did not produce the desired results due to their vitiation. 


\subsection{Varying Standards}

Values do not change immediately with a change of civil service regime (Ryan, 2004). However, values-based management can produce positive effects on the public sector (McCourt, 2007). Long-held traditions can also affect developmental and institutional outcomes (Lange, 2004). This was most keenly observable in areas where new local governments in Pakistan were given the opportunity to take initiatives but remained dependent on the skills of the civil service.

Local government ordinances allowed local governments to lay down local regulations. This was an important provision with the potential to encourage innovation and the adoption of locally suited solutions. If used to its fullest intent, local regulations could well create entirely different domains to supplant the uniform civil service codes and sectoral regulations that had evolved over decades. At the same time, the local governments inherited civil servants who had been trained to maintain uniform standards and did not have much incentive to look beyond them. For the civil servants, the expected technical engines of change and support for local initiatives, there was little incentive to experiment with new regulations and innovation. The approach was almost overwhelming in the four provinces, all of which carried a heavy burden of tradition. Even provincial legislation and rules seldom varied much for each other.

The existence of uniform standards can have a two-way relationship with centralized civil service management. Uniform standards are an outcome of a centralized civil service since a central authority regulates both domains. On the other hand, a centralized civil service gains validity through uniform standards and procedures, which reduce the cost of learning and adjustment when central civil servants are posted to subnational jurisdictions. Both outcomes mutually reinforce each other.

The local government reforms of 2001 made a reluctant and somewhat antithetical departure from this practice. The ordinances included provisions for local regulations. In the Sindh Local Government Ordinance, the Fifth Schedule listed 21 items for local rules and 42 subjects for local byelaws. ${ }^{12}$ The last provision in each case was a general enabling clause without limiting the subject for such local legislation. These provisions, once put into practice, would create diversified standards across the country. While this was a major step forward, the four local

\footnotetext{
${ }^{12}$ See Sindh, Local Government Department (2001) for details.
} 
governments were themselves centrally prepared at the federal level under a rigid framework aiming at uniformity. This stamp of uniformity continued to inhibit the growth of local initiatives. Central civil servants assigned to the local governments did not help. By training and by inclination, they continued to find solutions to different local problems through their learned behavior of applying narrowly conceived rules and regulations. As a result, local regulations were adopted only in a small number of districts and in areas of little significance.

In the interplay of these opposing forces, local governments did, however, create multiple organizations. Civil servants placed in the districts were much more attuned to local issues than deconcentrated offices implementing provincial policies and programs. A two-way channel of communication was opened between districts and provincial departments. One of the key concerns voiced by senior provincial civil servants in this period was the deterioration in service standards. In many cases, this complaint referred to the weakening of uniform standards under local initiatives rather than deterioration against a universal standard.

Comparative discussions with senior civil servants indicated that this might be the case. For example, comparisons between centrally managed engineering departments such as public health engineering and local government water supply outfits always rated the former as better performing. This was not, however, borne out by the evidence. There were differences between the types and scales of operation. Public health engineering was responsible for drinking water supply in rural areas while the local government water supply was restricted mostly to urban areas, with the exception of large urban centers. Despite these differences, when the local water supply department had accumulated unpaid electricity bills-around PKR 3.5 billion in 2004 for 122 TMAs in Punjab-the public health engineering department lagged far behind in cost recovery and the amount of subsidy was much higher. Most senior civil servants in criticizing local governments standards applied a hypothetical counterfactual instead of the reality of the situation prior to 2001. The analytic conclusion was, therefore, not surprising. At the same time, the increasing concern with deteriorating standards was perhaps indirect evidence that some local initiatives and norms were taking shape.

\subsection{Decreased Translucency of Offices}

A major change brought about by decentralization and the creation of a large number of elected councils was the demystification of much of 
the public sector. For the first time, large sectors such as education, health, road building and maintenance, water and sanitation, agriculture extension and, in some cases, land administration became open to review by local councils. The centrally managed civil service had been accustomed to management in the name of the people through the concept of public interest. Now, elected councils' oversight and inputs in major sectors caused hitherto undefined public interest to wither, replacing it with the legitimized intervention of people's representatives.

However, instead of this becoming the engine for civil service activities, direct policy instructions and citizen choices emerging from local political processes provided directions. This process was not linear or error free. It was commonly reported that councilors did not clearly understand what local departments could do. Many councilors complained of a lack of authority, as they could not have teachers transferred when they so desired. In time, this may translate into learning the ways in which departments work, but compared with the district administration of a decade ago, it was still a major change. Citizens became increasingly aware of what different departments did and did not do, generating pressure on the civil service.

In responding to the new demands for service delivery, a fresh set of skills was required. The strong suit of implementation in Pakistan was the central management of training. This helped avoid the pitfalls of decentralized management of training, which might otherwise lead to differential outcomes. ${ }^{13}$ The training and retraining of civil servants during this period remained unaffected by the new job descriptions. Only training that credibly addressed the need for new skills for budgeting and financial management was carried out.

\subsection{Exposure of Performance at Multiple (Lower) Levels}

An unintended consequence of devolved government was the creation of windows of observation that highlighted civil service performance. Not only did districts and TMAs became stages on which civil servants could transparently perform their roles with visible outcomes, but within each of them individual offices were now visibly responsible for sectoral performance and outcomes. Indirect evidence of this consequence of devolved government was the public debate surrounding service delivery failures. Senior provincial civil servants again served as an indirect barometer of the changing outlook. Earlier, only those

\footnotetext{
${ }^{13}$ For a study of this issue with reference to the Ukraine, see Witesman and Wise (2009). They attribute centralization to the higher uptake of training toward democratization and planning capacities.
} 
who had worked in planning and development posts would be concerned with service delivery. Others steeped in general management and its higher concerns would have hardly found it sufficiently interesting or worth their while.

The Social Action Program 1992-2000, for example, could not find champions in deconcentrated offices of civil administration despite repeated attempts to engage them. From 1997 to 1999, in the NWFP, the task of commissioning new schools was decentralized to regional commissioners. Over three years, the purchase of furniture, and obtaining electricity connections and water supply progressed very slowly. In 19961999, the Government of Punjab developed a proposal to post civil service officers as additional deputy commissioners for literacy. This newly created position was designated thus to connect it prestigiously with the civil administration in order to woo civil officers into the management of education department. Despite these efforts, the positions remained unattractive and education did not measure very highly on the list of desirable civil service positions.

The local government reform of 2001 brought about a material change. District positions were solidified and made responsible for service delivery. The largely moribund public order functions of the civil service were assigned to the police as they desired. Without necessarily agreeing with the merit of this abolition, the new institutional arrangement formally conglomerated responsibilities and certain functions under the DCO. This spurred new interest in service delivery. District managers under the local government scheme demanded training to equip them to serve in the enhanced role of service delivery management since their earlier training had focused almost exclusively on the administration of criminal and land administration laws. Provincial departments and local councils demanded improvements in service delivery in measurable ways. Civil service performance methods were given the opportunity for tangible performance to be rewarded and linked with career development. The system, however, did not avail this opportunity.

With the local government reforms, new offices for functions such as finance and planning were created at the district level. Officers with five to eight years of experience were assigned to these offices. The new position of EDO Finance and Planning was a culmination of the efforts of the 1990s to create offices for development planning at the subprovincial level. Under the deconcentrated arrangement, planning officers were created in the provincial divisions, one for each group of districts. The planning offices reported to the Planning and Development Department 
and did not have the capacity to carry out sectoral planning. They performed limited functions relating to project appraisal, and carried a wider mandate of planning for the district. Earlier officers with this work experience would have had relatively subordinate roles in the Planning and Development Department. The new offices created a demand for careful budgeting processes and decisions at the local level. This followed the argument that public management follows budgeting structures rather than the other way round. ${ }^{14}$

Officers were, however, posted without much preparation. Those with experience of working in the Planning and Development Department were technically qualified for project appraisal and basic capital budgeting, while others with a civil administration background were not well equipped for the role. The new offices did not, therefore, fulfill their potential. The departments continued to work through vertical programs, centralizing much of the planning function assigned to local governments. Compared with the district capital budgets, vertical programs continued to channel larger resources into local functions and their development (Cyan \& Porter, 2006).

\subsection{Comparative Evaluation and Yardstick Competition}

The civil service was unaccustomed to comparative evaluation. Under centralized management, district administrations were, at best, compared in terms of revenue recovery and, earlier, in the disposal of criminal cases. Other administrative aspects were not compared. However, after the local government reforms, districts were compared in terms of education and health outcomes.

A key motivation for district-level comparisons was the insertion of provincial finance commissions in the local government ordinances in July 2002. For the first time in Pakistan, the principle of rational distribution of resources at the subprovincial level was recognized. This generated a demand for district-level statistics and performance measures. The Federal Bureau of Statistics, which had considered compiling district-level survey statistics a very difficult task in 2001, started producing the district-disaggregated Pakistan Living Standards Measures survey by 2008. Other surveys such as the Multiple Indicator Cluster Survey showed different districts' health outcomes in stark relief. Districts also produced education statistics.

14 See Rouban (2008) for a discussion on the effects of decentralization in this regard with reference to the 1986 decentralization reforms in France. 
DCOs were held accountable for district performance in education and health, largely at province-level meetings. The horizontal yardstick competition that started with the publication of district statistics for each sector played a stronger influence, however. A civil service that had been used to meeting staid rules and standards in pursuit of an undefined public interest was now exposed to chasing tangible numbers. This generated a demand for management skills, initiative, planning, and decision-making that had earlier been confined mostly to public order situations.

\section{Conclusion}

The civil service in Pakistan is perceived as an organization capable of effectively implementing government policy and programs. Under decentralization, it was exposed to the twin challenges of meeting programmatic outputs as well as responding to local democracy. It is not necessary to assume that central programmatic goals are very different from the choices that emerge from local democracy. Political process at the local level may vary inputs, levels, the mix of services, and timing. It may enforce a tighter or looser accountability for performance. On the whole, local democracy, where variety is certain, reduces certainty for a centrally attuned civil service. Devolution in Pakistan from 2001 to 2009 changed structures as well incentives for civil servants. In responding to these, civil servants' choices varied from adapting to their new environment to reshaping it. The latter can be seen a form of optimizing behaviorrebalancing central versus local control through civil service rules, emerging norms, relationships, and tenures.

Decentralization may change structures and affect incentives for central civil servants in local jurisdictions. On average, civil servants respond by pursuing career paths under changed circumstances. When the process of decentralization is not sufficiently aware of the details, civil servants may redefine decentralization mechanisms in ways that are imperceptible but important. In the case of Pakistan, the redefinitions continued through this period through details of rules and other mechanisms. Finally, decentralization outcomes differed from those initially intended. Local innovation was curtailed due to central influences. Civil servants found their incentives linked with central authorities and program objectives. At the same time, local governments remained weak and unable to benefit from civil servants' expertise and harness it toward locally defined sectoral priorities. 


\section{References}

Asian Development Bank, UK Department for International Development, World Bank. (2004). Devolution in Pakistan. Islamabad, Pakistan: Authors.

Brinkerhoff, D. W. (2008). The state and international development management: Shifting tides, changing boundaries, and future directions. Public Administration Review, 68(6), 985-1001.

Cole, A., Jones, B. J., \& Storer, A. (2003). Inside the National Assembly for Wales: The Welsh Civil Service under devolution. Political Quarterly, 74(2), 223-232.

Cyan, M. R. (2009). Contract employment policy review. Unpublished report prepared for the Asian Development Bank.

Derlien, H.-U. (2003). Mandarins or managers? The bureaucratic elite in Bonn, 1970 to 1987 and beyond. Governance, 16(3), 401-428.

Evans, A., \& Manning, N. (2003). Decentralization: A review of staffing practices in eight countries. Draft paper prepared for the World Bank, Washington, DC.

Goodwin, M., Jones, M., \& Jones, R. (2005). Devolution, constitutional change and economic development: Explaining and understanding the new institutional geography of the British state. Regional Studies, 39(4), 421-436.

Gulrajani, N. (2010) New vistas for development management: Examining radical-reformist possibilities and potential. Public Administration and Development, 30(2), 136-148.

Lange, M. K. (2004). British colonial legacies and political development. World Development, 32(6), 905-922.

McCourt, W. (2007). Impartiality through bureaucracy? A Sri Lankan approach to managing values. Journal of International Development, $19,429-442$.

McGregor, E. B., Jr. (1974). Politics and the career mobility of bureaucrats. American Political Science Review, 68, 18-26.

Meyer, R. E., \& Hammerschmid, G. (2010). The degree of decentralization and individual decision making in central government human 
resource management: A European comparative perspective. Public Administration, 88(2), 455-478. Ongaro, E. (2008). Introduction: The reform of public management in France, Greece, Italy, Portugal and Spain. International Journal of Public Sector Management, 21(2), 101-117.

Pakistan, Ministry of Education, and UNESCO. (2003). Quality of primary education in Pakistan. Islamabad, Pakistan: Authors.

Parry, R. (2005). The civil service response to modernization in the devolved administration. Financial Accountability and Management, 21(1), 57-74.

Parry, R. (2008). Changing UK governance under devolution. Public Policy and Administration, 23(1), 114-120.

Peters, B. G. (2008). The Napoleonic tradition. International Journal of Public Sector Management, 21(2), 118-132.

Punjab, Services and General Administration Department. (2004). Punjab management service rules 2004. Lahore, Pakistan: Author.

Pyper, R. (1999). The civil service: A neglected dimension of devolution. Public Money and Management, 19(June), 45-49.

Rouban, L. (2008). Reform without doctrine: Public management in France. International Journal of Public Sector Management, 21(2), 133-149.

Ryan, J. J. (2004). Decentralization and democratic instability: The case of Costa Rica. Public Administration Review, 64(1), 53-67.

Sindh, Local Government Department. (2001). Sindh local government ordinance 2001. Karachi, Pakistan: Author.

Williamson, T., Ahmad, M., \& Smith, S. (2005). Improving devolved social services in Punjab and NWFP. Islamabad, Pakistan: Asian Development Bank and UK Department for International Development.

Witesman, E. A., \& Wise, C. R. (2009). The centralization/decentralization paradox in civil service reform: How government structure affects democratic training of civil servants. Public Administration Review, 69(1), 116-127.

World Bank. (2004). Civil service reform and decentralization. Retrieved from http://www.ciesin.org/decentralization/English/Issues/CSR.html 